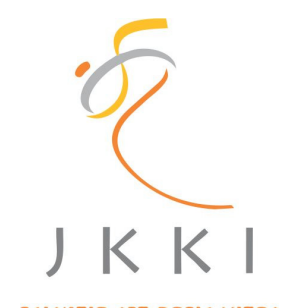

Jurnal Kedokteran dan Kesehatan Indonesia

\author{
Indonesian Journal of Medicine and Health
}

Journal homepage: https://journal.uii.ac.id/JKKI

\title{
Digital image analysis of immunohistochemistry KI-67 using QuPath software in breast cancer
}

Hermin Aminah Usman*1, Fauzan Ali Zainal Abidin ${ }^{1}$

${ }^{1}$ Department of Anatomical Pathology, Faculty Medicne, Universitas Padjadjaran, Hasan Sadikin General Hospital, Bandung, Indonesia

Original Article

\begin{tabular}{l}
\hline \\
\hline ART ICLE INF O \\
\hline Keywords: \\
Ki67, \\
digital image analysis, \\
QuPath, \\
breast cancer \\
*Corresponding author: \\
hermin@unpad.ac.id \\
\hline DOI:10.20885/JKKI.Vol12.Iss1.art7 \\
\hline History: \\
Received: August 7, 2020 \\
Accepted: February 23, 2021 \\
Online: April 30, 2021 \\
\hline Copyright @2021 Authors. \\
This is an open access article \\
distributed under the terms \\
of the Creative Commons At- \\
tribution-NonCommercial 4.0 \\
International Licence (http:// \\
creativecommons.org/licences/ \\
by-nc/4.0/).
\end{tabular}

\section{ABSTRACT}

Background: Today, pathology services are more developed for quantitative diagnostic evaluation. The quantitative diagnostic evaluation requires detailed accuracy and can be done using digital image analysis (DIA). Assessment of the Ki67 labelling index (LI) in breast carcinoma needs to be done quantitatively. A visual evaluation of Ki67 LI using light microscopy has high inter-observer variability. The evaluation of Ki67 LI could be done digitally with the DIA technique to overcome the interobserver variability. The DIA technique is carried out by counting the Ki67 LI manually or automatically with bioimage analysis software. QuPath is one of the bioimage analysis software, has characteristics of crossplatform, intended for bioimage analysis and digital pathology.

Objective: This study aims to compare the manual and automatic calculation of Ki67 LI digitally.

Methods: This study was a cross-sectional study; a total of 240 digital Ki67 images from 30 slides were analyzed by counting manually and automatically using QuPath.

Results: Statistical analysis using the T-test showed no significant difference between the manual and automatic counting of Ki67 LI ( $p=$ $0,801, \alpha=0,05$ ).

Conclusion: Digital image analysis using QuPath can be used to calculate the Ki67 LI automatically.

\footnotetext{
Latar Belakang: Saat ini pelayanan patologi lebih berkembang kepada diagnostik bersifat evaluasi kuantitatif. Untuk itu diperlukan akurasi yang detil dengan menggunakan analisis pencitraan digital. Evaluasi nilai indeks Ki67 pada karsinoma payudara perlu dilakukan secara kuantitatif. Evaluasi indeks Ki67 secara visual menggunakan mikroskop cahaya memiliki nilai variabilitas antar pengamat yang cukup tinggi. Untuk mengatasinya, maka dapat dilakukan teknik analisis pencitraan digital terhadap evaluasi indeks Ki67 baik dengan penghitungan manual atau otomatis dengan bantuan perangkat lunak secara digital. QuPath adalah perangkat lunak lintas-platform yang ditujukan untuk analisis pencitraan biologis dan patologi digital.

Tujuan: Tujuan penelitian ini adalah untuk mengetahui perbedaan hasil penghitungan manual dan otomatis nilai indeks Ki67 secara digital.

Metode: Penelitian ini menggunakan desain potong lintang. Jumlah total sampel sebanyak 240 pencitraan Ki67 digital dari 30 preparat yang dianalisis menggunakan QuPath secara manual dan otomatis.

Hasil: Analisis statistik menggunakan Uji T menunjukkan tidak terdapat perbedaan secara signifikan antara hasil penghitungan nilai indeks Ki67 secara manual dibandingkan dengan otomatis ( $p=0,801, \alpha=0,05)$.

Kesimpulan: Analisis pencitraan digital dengan menggunakan QuPath dapat digunakan dengan baik untuk menghitung nilai indeks Ki67 secara otomatis.
} 


\section{INTRODUCTION}

The development of pathology is highspeed. Previous pathology services prioritized qualitative diagnostic based on holistic pathological judgment and relatively limited clinical information. At present, pathology services are more developed for diagnostics that are semi-quantitative and quantitative evaluations of pathological conditions and biomarker expression. In this case, anatomical pathology becomes more quantitative or analytical. Therefore, the diagnostic process needs more accuracy. ${ }^{1}$ There are many imaging analysis software created for better diagnostic accuracy to carry out various types of quantitative pathology diagnostic tasks and research. ${ }^{2}$

One of the quantitative evaluations of the expression of the biological markers is to assess cell proliferation activity. Cell proliferation activity of malignant tumours is an important prognostic factor that has a role in managing both operative and non-operative therapy. This management also applies to breast cancer to determine between tumours that have high proliferation or low proliferation. ${ }^{3,4}$ Dowsett et al. in their study have recommended the use of Ki67 as a marker of proliferation, especially in breast cancer. ${ }^{5,6} \mathrm{Ki} 67$ is a protein expressed in all phases of the cell cycle except for the G0 phase. ${ }^{4,5}$ Proliferating tumour cells show a positive reaction in the cell nucleus against Ki67 antibodies. This characteristic makes Ki67 the best marker to be detected by immunohistochemical techniques in various types of malignant tumours, including breast cancer. Ki67 labelling index (LI) is the percentage value of the distribution of tumour cells positively stained by Ki67 antibodies. The method calculates the number of positive tumour cells in the nuclei divided by the total tumour cells. ${ }^{7}$ Various studies provide evidence that a high Ki67 LI value indicates an increased risk of recurrence, metastasis, and rapid breast cancer development. ${ }^{4,8}$ Besides, the Ki67 LI is also used to determine tumour grading as neuroendocrine tumours. The higher the Ki67
LI in neuroendocrine tumours, the higher the tumour grade. ${ }^{9}$

Evaluation of Ki67 LI is generally carried out semi-quantitatively by pathologists using a light microscope at low magnification. This technique of evaluation is called the visual microscopic evaluation. Because of the critical role of Ki67 mentioned above, the reproducibility of the evaluation of Ki67 LI is fundamental. Voros et al. in their research, showed that the reproducibility of the Ki67 LI using visual microscopic evaluation under a microscope was not optimal because of the high interobserver variability. ${ }^{10}$ Thus, it is necessary to evaluate the Ki67 LI quantitatively, which can be done digitally with bioimage analysis software. This technique is called digital image analysis (DIA). Evaluation of Ki67 LI with digital image analysis technique can be done by manual counting and automatic counting.

Some software for analysis of digital imaging Ki67 is commercially available. However, they require considerable costs to obtain the software. Generally, they can only be used on computers with certain specifications. ${ }^{2,11}$ In addition to commercial software, researchers have developed software that can be used freely (freeware) for digital imaging analysis, one of which is QuPath. QuPath is a crossplatform, open-source software developed at the University of Edinburgh, aimed at biological imaging analysis and quantitative digital pathology. ${ }^{6}$ QuPath supports all types of computer operating systems. This software was developed as an application that can be used on Windows-based computers, Mac OS $\mathrm{X}$, and Linux to support many applications and various imaging files for pathology and bioscience analysis. ${ }^{6}$ The QuPath open-source software platform (The QuPath software can be downloaded at https://qupath.github.io/) was used to analyze the Ki67 LI in this study. ${ }^{6}$ This study is the first on the use of QuPath software in Indonesia. The use of QuPath for quantitative pathology evaluation is still rarely carried out by pathologists in Indonesia because the use of QuPath needs imaging devices. These imaging 
devices are used to capture the histopathology slide and convert it into a digital slide. That is why it is called digital image analysis. One imaging device that would maximize the use of QuPath is the whole slide scanner. However, in Indonesia, there are only a few anatomical pathology laboratories that have this facility. Nevertheless, the presence of digital pathology is inevitable. Once the issue of completing facilities and infrastructure in anatomical pathology laboratories can be resolved, the use of QuPath will significantly assist in evaluating quantitative pathology evaluation using DIA. This study aims to determine the differences in the manual and automatic calculation of Ki67 LI performed digitally using QuPath software.

\section{METHODS}

The Ethics Committee of the Hasan Sadikin General Hospital, Bandung, approved this study's ethical clearance (LB.02.01/X.6.5/159/2017). The samples are Ki67 stained preparations from patients diagnosed histopathologically with invasive breast carcinoma in Hasan Sadikin General Hospital Bandung. A total of $30 \mathrm{Ki} 67$ stained slide preparation samples were randomly selected from July 2017 until December 2017.

\section{Ki67 staining}

The breast cancer tissue in paraffin blocks was randomly selected from the Anatomical Pathology department Hasan Sadikin Hospital. The tissue was cut with a thickness of $4 \mu \mathrm{m}$ using a microtome, then depleted with xylol, rehydrated with decreased ethanol concentration, then immersed in PBS in 15 minutes ( $3 \times 5$ minutes). The tissue pieces were then incubated in Dako Antigen Retrieval Buffer (Dako, Santa Clara, California, USA) in microwave $94^{\circ} \mathrm{C}$ for 20 minutes and followed by cooling at room temperature for 20 minutes and washed with PBS for 15 minutes (3x5 minutes), then incubated in Block Peroxidase for 10 minutes, PBS for 10 minutes and followed by incubation in Ki67 rabbit monoclonal antibody (clone MRQ-64, Cell Marque, Burlington, USA, at $1: 100$ dilution) at $4^{\circ} \mathrm{C}$. After incubation with Ki67, the preparations were then reincubated with secondary antibodies Labeled Polymer HRP (Dako, Santa Clara, California, USA) for 60 minutes at room temperature. Lastly, the counterstain phase was stained with Hematoxylin Meyer, then dehydrated with increased ethanol concentration, purification in xylol then the slide was covered with a cover glass.

\section{Imaging process}

The imaging process did not use the whole slide scan technique because it was not available in our Department. To overcome this, we divided each Ki67 preparation into eight compartments by using a diamond point marker (Thermo Fisher Scientific ${ }^{\mathrm{TM}}$, Massachusetts, USA). A 400X magnification field is selected from each compartment that is consistent in one area in each compartment. The chosen field of view is in the right area of the compartment (Figure 1).

Imaging was carried out at $400 \mathrm{X}$ magnification using a light microscope Olympus BX51 model equipped with an Olympus XC10IR colour camera connected directly to a computer with a 32-bit Microsoft Windows XP SP 2 operating system. The processor used is Intel Pentium 4 and 1,016 GB of randomaccess memory (RAM). Digital imaging of Ki67 preparations was taken using dotSlide version 2.0 software with $2560 \times 1920$ pixels resolution at 8 -bit colour depth and saved

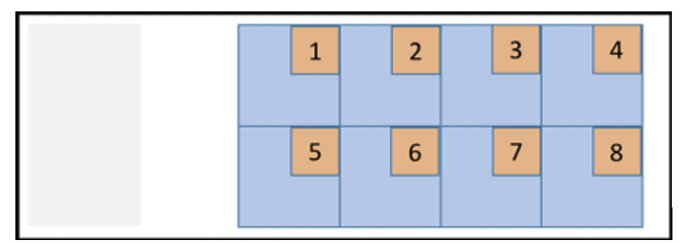

Figure 1. Compartments on Ki67 slide 
as joint photographic experts group (JPEG) format. A total of $240 \mathrm{Ki} 67$ images at 400X magnification were obtained and stored on the computer. Ki67 images were then analyzed using QuPath software on a computer with macOS operating systems. The processor used is $2.9 \mathrm{GHz}$ Intel Core i5 and 8Gb of RAM.

\section{Manual counting of Ki67 digital image analysis}

Images taken from each preparation were analyzed by manual counting with the QuPath software. Two pathologists did the manual counting. The first step of manual counting digital image analysis is done by activating the show grid to facilitate the cell counting area. Then select the point tool so that the counting panel appears. To start counting cells is done by clicking the cursor on the positive tumour cells. The criteria for positive tumour cells are the cells with brown coloured in the tumour nuclei. Ki67 positive tumour cells are marked with red points. After finishing clicking positive tumour cells, add a new annotation to the counting panel to calculate the negative tumor cell Ki67. The criteria for negative tumour cells are the cells with blue colored in the tumor nuclei. Click the cursor on the negative tumour cell in the same way as before; the negative tumour cell Ki67 is marked with a blue dot (Figure 2).

The number of positive and negative tumour cells will be displayed on the counting panel. The results of the Ki67 LI digital imaging by manual calculation are obtained by the formula as follow:

$$
\text { Manual Ki67 LI }=\frac{P}{P+N} \times 100 \%
$$

$\mathrm{P}=$ The number of Ki67 positive tumour cells. $\mathrm{N}=$ The number of Ki67 negative tumour cells.

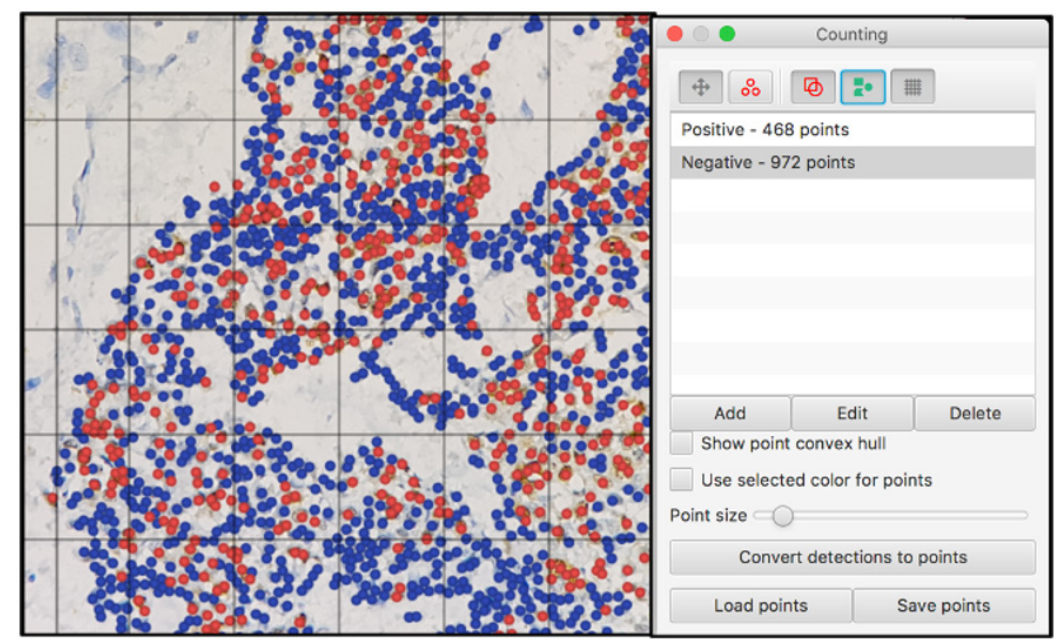

Figure 2. Manual counting of Ki67 digital imaging

\section{Automatic counting of Ki67 digital image analysis}

Images of Ki67 from the same preparation as manual calculation was then calculated automatically with the QuPath software (automatic counting by digital image analysis). The algorithm of automatic counting uses color deconvolution and cell segmentation algorithms (watershed cell detection). The first step was done by selecting the buttons, including the analyze, cell analysis, and positive cell detection.
Then the dialog box of cell detection parameters appeared, all related parameters was entered, and the run button was clicked. The parameters used for calculating the Ki67 index as in a study by Bankhead et al. ${ }^{6}$

QuPath will count automatically and display the number of Ki67 positive tumour cells, the number of negative tumour cells Ki67, and the results of digital Ki67 imaging automatic counting in percentage (Figure 3). 


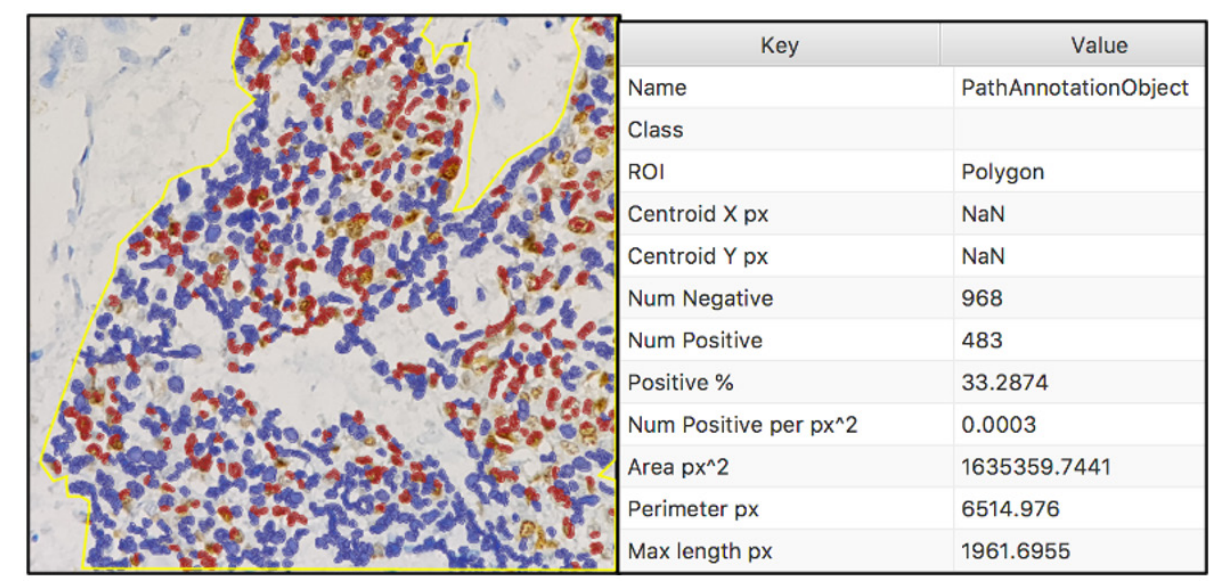

Figure 3. Automatic counting of Ki67 Digital imaging

\section{Statistical analysis}

Statistical analysis was performed using SPSS Version 23 for macOS (SPSS, Chicago, Illinois, USA). Cohen's $\kappa$ assessed Intraobserver reliability. Weighted $\kappa$ coefficients with absolute weighting were computed for manual countings of Ki67 DIA, which the two pathologists did. Kappa values of $0-0.20$ were considered poor, $>0.20-0.40$ fair, $>0.40-0.60$ moderate, $>0.60-$ 0.80 good and $>0.80-1$ excellent.

The results of the Ki67 index calculation manually and automatically are statistically analyzed using paired sample T-tests. The
HO hypothesis is that there is no significant difference in the results of the Ki67 LI obtained by manual DIA compared to automatic DIA countings.

\section{RESULTS}

\section{Manual countings of Ki67 LI digital image analysis reliability}

The kappa values and confidence interval for the interobserver concordance are shown in Table 1. Both manual countings of the Ki67 LI DIA from two pathologists showed good intraobserver reliability.

Table 1. Interobserver reliability of Ki67 LI manual counting by digital image analysis

\begin{tabular}{lccc}
\hline & Category & Kappa & 95\% CI \\
\hline Manual counting of Ki67 LI DIA & Excellent & 0.829 & $0.99-1.00$ \\
\hline LI, labeling index; DIA, digital image analysis & &
\end{tabular}

\section{Manual and Automatic countings of Ki67 digital image analysis}

The manual and automatic counting of the Ki67 digital image analysis were shown in Table 2. The mean digital image analysis of Ki67 LI with manual counting was $41.83 \%$, and automatic counting was $42.93 \%$. The average difference of the Ki67 LI of manual and automatic counting was $7.02 \%$.

The statistical analysis paired sample T-test on digital image analysis of the Ki67 LI counted manually compared to automatically is shown in Table 3. The table shows the comparison of the manual and automatic counting of Ki67 LI digital image analysis. It can be concluded that there was no significant difference between the results of the Ki67 LI digital image analysis obtained by manual counting compared to automatic counting ( $p=0.801$ ) 
Table 2. The results of manual and automatic counting of the Ki67 LI digital image analysis

\begin{tabular}{|c|c|c|c|}
\hline $\begin{array}{c}\text { Sample } \\
\text { No. }\end{array}$ & $\begin{array}{l}\text { Manual counting } \\
\text { Ki67 LI DIA(\%) }\end{array}$ & $\begin{array}{l}\text { Automatic counting } \\
\text { Ki67 LI DIA(\%) }\end{array}$ & $\begin{array}{l}\text { Difference manual and } \\
\text { automatic Ki67 LI DIA (\%) }\end{array}$ \\
\hline 1 & 27.50 & 41.50 & 14,0 \\
\hline 2 & 82.30 & 60.80 & 21.5 \\
\hline 3 & 47.00 & 51.00 & 4,0 \\
\hline 4 & 35.70 & 39.80 & 4.1 \\
\hline 5 & 13.60 & 27.20 & 13.6 \\
\hline 6 & 48.60 & 43.10 & 5.5 \\
\hline 7 & 44.40 & 40.90 & 3.5 \\
\hline 8 & 40.30 & 43.40 & 3.1 \\
\hline 9 & 63.10 & 66.40 & 3.3 \\
\hline 10 & 73.20 & 77.10 & 3.9 \\
\hline 11 & 29.20 & 40.90 & 11.7 \\
\hline 12 & 35.40 & 48.50 & 13.1 \\
\hline 13 & 37.30 & 42.30 & 5,0 \\
\hline 14 & 27.40 & 32.80 & 5.4 \\
\hline 15 & 16.80 & 15.00 & 1.8 \\
\hline 16 & 40.90 & 40.00 & 0.9 \\
\hline 17 & 48.10 & 45.10 & 3,0 \\
\hline 18 & 9.80 & 19.70 & 9.9 \\
\hline 19 & 33.00 & 42.40 & 9.4 \\
\hline 20 & 64.70 & 63.90 & 0.8 \\
\hline 21 & 15.10 & 17.50 & 2.4 \\
\hline 22 & 18.20 & 9.60 & 8.6 \\
\hline 23 & 70.10 & 66.10 & 4,0 \\
\hline 24 & 7.20 & 19.80 & 12.6 \\
\hline 25 & 41.00 & 39.30 & 1.7 \\
\hline 26 & 44.50 & 40.50 & 4,0 \\
\hline 27 & 23.90 & 30.20 & 6.3 \\
\hline 28 & 83.90 & 67.10 & 16.8 \\
\hline 29 & 52.80 & 44.00 & 8.8 \\
\hline 30 & 80.00 & 72.10 & 7.9 \\
\hline Mean: & 41,83 & 42,93 & 7,02 \\
\hline
\end{tabular}

LI, labeling index; DIA, digital image analysis

Table 3. Mean comparison of manual and automatic counting of Ki67 LI digital image analysis

\begin{tabular}{lccccc}
\hline & Mean & SD & $\begin{array}{c}\text { Mean } \\
\text { comparison }\end{array}$ & p & CI 95\% \\
\hline Manual counting Ki67 LI DIA & 41.83 & 22.68 & 7.02 & 0.801 & $7.86-10.10$ \\
Automatic counting Ki67 LI DIA & 42.93 & 18.73 & &
\end{tabular}




\section{DISCUSSION}

Digital image analysis in pathology is one of the methodologies in computer-assisted pathology. ${ }^{12}$ The approach of assessing digital images of histological slides is gaining momentum in today's laboratory environment. Indeed, most digital image acquisition systems are becoming routine, and associated image analysis solutions are regarded by most as the next significant level in automated histological analy. ${ }^{1,11}$

Although a pathologist's assessment is the gold standard in diagnosis, there are many warnings with this method. For individuals, fatigue may potentially be a problem in a profession always in demand. These problems are no more a problem with machines, which may be used to increase the output of histological assessment. ${ }^{2,12}$ It is fully recognized, however, that automated image analysis may never progress into a diagnostic circumstance because of the natural differences between individual slides and the importance of an accurate diagnosis. Another major problem relates to IHC staining and its evaluation. ${ }^{12}$ IHC staining can vary between slides and between antibodies, whereas specimen fixation and processing conditions may cause incompatibility between samples. ${ }^{1,6,12}$ This problem suggests an essential condition to standardize staining procedures and sample preparation protocols before using automated image analysis techniques. This problem is specifically vital in clinical situations where IHC testing assists in therapeutic decisionmaking, such as in breast cancer. There is also often variability between evaluators as another problem of the pathologist's assessment. For example, each pathologist must take up their semi-quantitative scoring system (commonly numerically describing staining as $0,1+, 2+$, or $3+$ ), based on the darkest/lightest staining in the set of slides they are looking at. This method of the semi-quantitative scoring system leads to inconsistencies between pathologists because this approach is simply subjective. ${ }^{11,12}$

Automated image analysis procedures are beginning to be commonly used for biomarker evaluation in a research context due to the difficulty in the manual scoring of IHC, as discussed previously. This difficulty circulates the IHC technique's reproducibility as a whole and the human eye's capability to distinguish between $1+$ and $2+$ scores. Computational evaluations offer the potential to solve this issue for the quantification of the IHC staining. 1,2,12

One evidence of malignancies is uncontrolled cell proliferation. In invasive breast carcinoma, the Ki67 LI can be used as a proliferation marker and predictive marker for chemotherapy responses and has a role as a prognostic factor. $^{13,14}$ The Ki67 LI is critical to distinguish between molecular subtypes of Luminal A and Luminal B breast carcinomas. Dowsett et al., in their study, suggested that Luminal B breast carcinoma needs neoadjuvant chemotherapy, whereas Luminal A is not recommended for chemotherapy. ${ }^{5}$ Thus, standardization of the Ki67 LI analysis is considered necessary because of its impact on clinical conditions and treatment plans.

This researsch shows a pretty interesting phenomenon that the overall mean differences of manual and automatic DIA counting are only $1.1 \%$. In contrast, the case-by-case differences in the mean of manual and automatic DIA counting are $7.02 \%$. This phenomenon shows that although the overall differences are low, it turns out that there are relatively high differences when viewed on a case-by-case basis. Therefore, the automatic DIA counting needs some attention, that it still gives weakness. The result obtained from automatic counting of Ki67 LI DIA with QuPath tends to be higher (overestimated) than manual counting. Several factors can cause the predictions of the automatic counting of Ki67 LI with QuPath higher than the manual counting. This problem can occur because of non-tumour tissue such as lymphoid tissue and blood vessels in imaging. QuPath cannot distinguish tumour and non-tumour tissue areas. ${ }^{6}$ As a consequence, the non-tumour tissue area, will be counted as a tumour cell so that the Ki67 LI obtained is higher than the actual value. Despite the relatively higher overall difference of manual and automatic DIA counting in this study, the 
difference is more significant than the study results by Kostopoulos et al. which was 9.8\%. ${ }^{15}$

The accuracy of the automatic counting of KI67 LI can be improved. It is better to choose a region with little non-tumour tissue. In this study, the setting of cell detection parameters is shown in Figure 4. These parameters were chosen because, with this setting, the Ki67 LI was obtained most accurately and closest to the result of manual counting of Ki67 LI according to the research conducted by Bankhead et al. ${ }^{6}$

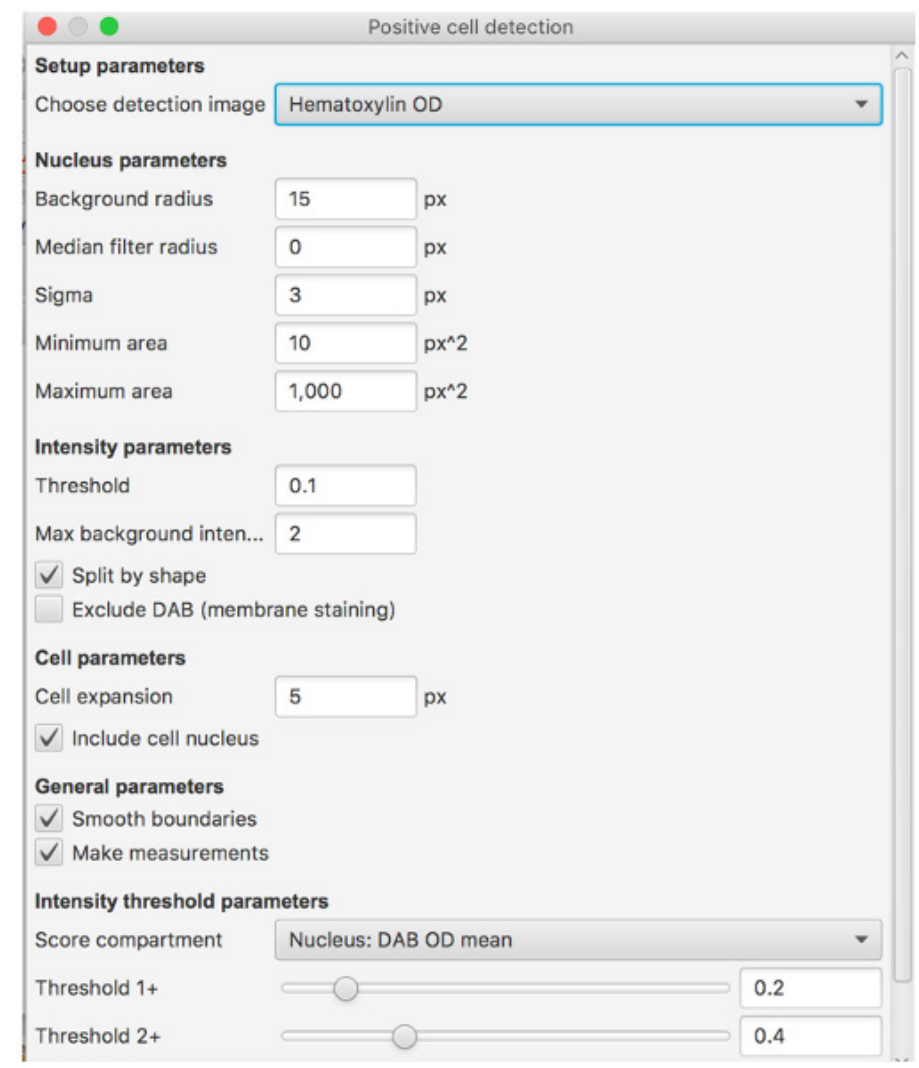

Figure 4. The setting parameter of cell detection in QuPath

This study shows that QuPath can be used to calculate the Ki67 LI automatically very well, even though it is not better than manual counting. The manual counting of Ki67 LI DIA is accurate because pathologists carry out the determination of tumour cells, and this could be the reference of the gold standard. The manual counting of Ki67 LI DIA also has excellent interobserver variability, as shown in the result with kappa value 0.829 . However, automatic counting has advantages in terms of the time needed to analyze the Ki67 digital image. The time needed to analyze the Ki67 digital image by manual counting is 15-30 minutes for one image, depending on its quality. The time needed by QuPath to analyze three images of Ki67 at once is 30 seconds. Thus, the large amounts of imaging data can be quickly and easily analyzed. ${ }^{15,16}$ Another advantage of automated digital image analysis is minimizing inter variability between observers when visually under a microscope. So that QuPath can be used as an alternative software for biological imaging analysis, especially in the field of histopathology because its use is relatively more manageable with a simple user interface. ${ }^{12,16}$

In several studies, analysis of digital imaging by Zhong et al. and Maeda et al. was done by making virtual whole slide analysis. ${ }^{7,17}$ In this study, imaging was not performed by the whole slides scan imaging technique but by dividing the preparation slides into eight compartments. This technique was used because of the limitations of 
the tools. From this study, it was found that the method of taking digital images without whole slides imaging could show good results because there is no significant difference between manual counting compared to automatic counting of the digital image. Even though imaging is not done in whole slides that require relatively expensive tools and software, the method of dividing compartments of preparation slides can still be done for research.

\section{CONCLUSION}

Digital imaging analysis techniques play an essential role in the quantitative evaluation of the Ki67 LI in invasive breast carcinoma. The manual counting of Ki67 LI DIA is more accurate than automatic counting. However, automatic counting of Ki67 LI DIA can be done for diagnostic and research purposes because the study results show no significant differences between automatic and manual counting of digital images.

\section{CONFLICT OF INTEREST}

The authors declare that there is no conflict of interest.

\section{ACKNOWLEDGEMENT}

The researcher would like to thank the Anatomic Pathology Department (especially for the head and staff), Medical Faculty Padjadjaran University, Hasan Sadikin General Hospital, who gave permission to conduct this study and assisted with laboratory examinations.

\section{REFERENCES}

1. Laurinavicius A, Laurinaviciene A, Dasevicius D, Elie N, Plancoulaine B, Bor C, et al. Digital image analysis in pathology: benefits and obligation. Analytical Cellular Pathology. 2012;35(2):75-8.

2. Webster JD, Dunstan RW. Whole-slide imaging and automated image analysis: Considerations and opportunities in the practice of pathology. Veterinary Pathology. 2014;51(1):211-23.

3. Luporsi E, Andre F, Spyratos F, Martin PM,
Jacquemier J, Penault-Llorca F, et al. Ki-67: Level of evidence and methodological considerations for its role in the clinical management of breast cancer: Analytical and critical review. Breast Cancer Research And Treatment. 2012;132(3):895-915.

4. Voros A, Csorgo E, Kovari B, Lazar P, Kelemen G, Cserni G. The use of digital images improves reproducibility of the ki-67 labeling index as a proliferation marker in breast cancer. Pathology Oncology Research. 2014;20(2):391-7.

5. Dowsett M, Nielsen TO, A'Hern R, Bartlett J, Coombes RC, Cuzick J, et al. Assessment of Ki67 in breast cancer: Recommendations from the International Ki67 in Breast Cancer working group. Journal of the National Cancer Institute. 2011;103(22):1656-64.

6. Bankhead P, Loughrey MB, Fernandez JA, Dombrowski Y, McArt DG, Dunne PD, et al. QuPath: Open source software for digital pathology image analysis. Scientific Reports. 2017;7(1):16878.

7. Zhong F, Bi R, Yu B, Yang F, Yang W, Shui R. A comparison of visual assessment and automated digital image analysis of Ki67 labeling index in breast cancer. PLoS One. 2016;11(2):e0150505.

8. Mohammed ZM, McMillan DC, Elsberger B, Going JJ, Orange C, Mallon E, et al. Comparison of visual and automated assessment of Ki-67 proliferative activity and their impact on outcome in primary operable invasive ductal breast cancer. British Journal of Cancer. 2012;106(2):383-8.

9. Klöppel G, La Rosa S. Ki67 labeling index: Assessment and prognostic role in gastroenteropancreatic neuroendocrine neoplasms. An International Journal of Pathology. 2018;472(3):341-9.

10. Voros A, Csorgo E, Nyari T, Cserni G. An intraand interobserver reproducibility analysis of the Ki-67 proliferation marker assessment on core biopsies of breast cancer patients and its potential clinical implications. Pathobiology. 2013;80(3):111-8.

11. Shaw EC, Hanby AM, Wheeler K, Shaaban AM, Poller D, Barton S, et al. Observer agreement comparing the use of virtual 
slides with glass slides in the pathology review component of the POSH breast cancer cohort study. Journal of Clinical Pathology. 2012;65(5):403-8.

12. Madabhushi A, Lee G. Image analysis and machine learning in digital pathology: Challenges and opportunities. Medical Image Analysis. 2016;33:170-5.

13. Yoshioka T, Hosoda M, Yamamoto M, Taguchi K, Hatanaka KC, Takakuwa E, et al. Prognostic significance of pathologic complete response and Ki67 expression after neoadjuvant chemotherapy in breast cancer. Breast Cancer. 2015;22(2):185-91.

14. Denkert C, Budczies J, von Minckwitz G, Wienert S, Loibl S, Klauschen F. Strategies for developing Ki67 as a useful biomarker in breast cancer. Breast. 2015;24 Suppl 2:S67-72.

15. Kostopoulos S, Cavouras D, Daskalakis A, Bougioukos P, Georgiadis P, Kagadis GC, et al. Colour-texture based image analysis method for assessing the hormone receptors status in breast tissue sections. Conference proceedings Annual International Conference of the IEEE Engineering in Medicine and Biology Society. 2007;2007:4985-8.

16. Volynskaya Z, Mete O, Pakbaz S, Al-Ghamdi D, Asa S. Ki67 quantitative interpretation: Insights using image analysis. Journal of Pathology Informatics. 2019;10(1):8-.

17. Maeda I, Abe K, Koizumi H, Nakajima C, Tajima S, Aoki H, et al. Comparison between Ki67 labeling index determined using image analysis software with virtual slide system and that determined visually in breast cancer. Breast Cancer. 2016;23(5):745-51. 